\title{
PENATALAYANAN GEREJA DALAM BIDANG PENDIDIKAN
}

\author{
Baringin Tirta Simarmata \\ bts_smart@yahoo.co.id \\ Hotner Tampubolon \\ hotnertampubolon@yahoo.com \\ Said Hutagaol \\ sodoguron_45@yahoo.co.id
}

\begin{abstract}
Abstrak
Kata penatalayanan (stewardship) adalah terjemahan dari kata Yunani Oikonomia. Kata ini dalam bahasa Yunani adalah kata majemuk, yang terdiri dari dua kata: oikos artinya rumah dan nomos artinya hukum. Karena itu menurut Kantonen (1956:2) kata oikonomia secara literal berarti hukum berhubungan dengan rumah, "the management of house or of household affairs" yang berarti suatu sistem pengaturan pelayanan atas suatu rumah atau dalam bidang kehidupan tertentu.Orang percaya (baca: gereja) sebagai pelayan memiliki panggilan dan tanggung jawab untuk mengurus (manage) setiap segi kehidupan di "rumah" (dunia) milik Tuhan ini agar menjadi semakin baik, indah, nyaman, tertib dan damai. Salah satu segi kehidupan yang menjadi tanggungjawab orang percaya (gereja) adalah segi pendidikan.Metode penulisan ini menggunakan kajian pustaka yang relevan dengan tugas panggilan gereja terhadap pendidikan. Tujuan penulisan ini adalah untuk membantu gereja (baik sebagai lembaga/institusi maupun sebagai individu/ person) untuk merumuskan dan mewujudkan tugas panggilannya dalam bidang pendidikan dengan perencanaan yang matang, pengorganisasian yang rapi dan pelaksanaan yang baik.
\end{abstract}

Kata kunci: Penatalayanan, gereja, pendidikan 


\section{A. PEndahuluan}

Penatalayanan boleh dipahami sebagai hal yang berkenaan dengan aktivitas menata, mengelola sekaligus memelihara sesuatu (berupa benda mati atau benda hidup maupun keduanya sekaligus). Aktivitas ini diemban seseorang sebagai pihak pelaksana berdasarkan amanat yang diterimanya dari pihak pemilik.

Mengupayakan dan mengembangkan pendidikan yang baik merupakan bagian amanat agung Tuhan (Mat 28:19-20). Tujuan pendidikan adalah mencerdaskan seluruh ciptaan Tuhan untuk membawa mereka pada pengenalan akan kasih Tuhan. Melalui pendidikan, diharapakan seluruh ciptaan, khususnya umat manusia mampu mengimplementasikan kasih Allah dalam kehidupan sehari-hari, baik terhadap sesama maupun lingkungannya.

Seorang pelayan adalah seorang yang penuh tanggungjawab dan diberi kuasa oleh tuan/ majikannya untuk mengurus kehidupan di seisi rumah. Pelayan tersebut yang mengatur semua hamba-hamba tuannya yang ada di rumah, bahkan berfungsi menjadi guru atau pendidik kepada anak-anak tuannya. Dia harus secara teliti dan cermat melaporkan dan mempertanggungjawabkan kepada tuannya segala sesuatu kehidupan di rumah tuannya tersebut. Contoh konkrit dari tugas penatalayanan ini dijumpai dalam kehidupan Yusuf di rumah Potifar di Mesir (Kej 37). Orang percaya (baca: gereja) hanya dipercayakan menatalayani milik di pemilik mutlak, yaitu Tuhan. Oleh karena itu, William B Girao(1992:88) berkata, "We are therefore managers, not owners of all that God has given".

Dalam misinya di dunia, gereja memiliki tugas panggilan dalam bidang pendidikan. Howard G Hendricks (1988:8) mengatakan gereja mesti melakukan pendidikan. Itu bukanlah sebuah pilihan melainkan suatu yang esensial; bukan hanya sekadar karena baik tetapi juga karena ia amat penting. Gereja yang berhenti melayankan pendidikan, ia telah berhenti sebagai sebuah gereja.

Pemahaman seperti itu jugalah yang menggerakkan para misionaris yang datang ke Indonesia, secara khusus para misionaris yang bekerja di tanah Batak pada masa zending, misalnya, memberi perhatian serius melakukan pelayanan di bidang pendidikan. Mereka bukan hanya memberitakan Injil, tetapi juga mengajari ilmu pengetahuan umum bahkan mendirikan sekolah di tempat mereka melayani.

Tugas panggilan yang sama juga hendaknya dilakukan oleh gereja yang hidup di abad ke-21 ini, yang tentu mempunyai tantangan yang berbeda dengan masa lampau. Namun demikian, esensi pendidikan yaitu untuk kebaikan 
hidup umat manusia dan seluruh ciptaan Tuhan tidak berubah sepanjang masa.

Pendidikan yang dimaksud di sini bukan hanya menyangkut sekolah, tetapi juga mencakup seluruh bidang kehidupan seperti dalam lingkungan keluarga dan masyarakat. Dalam hal ini, gereja perlu merumuskan dan mewujudkan tugas panggilannya dalam bidang pendidikan dimaksud dengan perencanaan yang matang, pengorganisasian yang rapi dan pelaksanaan yang baik.

Berikut ini dibahas menyangkut tugas panggilan gereja (sebagai lembaga dan warganya) dalam memajukan pendidikan

\section{B. PEMBAHASAN}

\section{Sekolah untuk kebaikan bersama}

Martin Luther, seorang tokoh reformator gereja, memandang pendidikan sebagai sesuatu yang sangat penting. Adrienne Jericho mengutip pandangan Luther $(2006 ; 147)$ menjelaskan bahwa melalui pendidikan generasi muda diperlengkapi dengan kemampuan dan pemahaman yang perlu untuk memberi sumbangan yang positif dalam kehidupan mereka. Pendidikan bukan hanya sekadar pengembangan diri atau penumpukan materi melalui pekerjaan dengan gaji yang tinggi, melainkan demi kebaikan bersama melalui pelayanan. Dengan berefleksi terhadap pandangan Martin Luther, gereja perlu menekankan pentingnya penatalayanan pendidikan.

Satu diantara sekian hal yang perlu mendapat perhatian dunia (dan karena itu perlu mendapat perhatian sekolah juga) adalah kesadaran setiap orang untuk menghargai perbedaan. Memang, sekolah-sekolah yang dikelola oleh gereja dapat menunjukkan kekhasannya dengan menanamkan nilai-nilai kristiani dalam seluruh proses pengajaran. Namun, hal ini tidak berarti bahwa sekolah menjadi "alat pengkristenan". Anak didik yang berlatar belakang agama lain tetap dihargai keyakinan agamanya. Dalam hal ini sekolah-sekolah kristen mesti menanamkan dan mempraktekkan sikap menghargai perbedaan latar belakang agama, etnis dan sebagainya. Sebab tali pengikat semuanya adalah kasih.

Living Values Educational Program, yang merupakan suatu kesepakatan kerja sama antar-pendidik di seluruh dunia yang didukung oleh UNESCO dan seksi pendidikan UNICEF menggali dan mengembangkan adanya dua belas nilai kehidupan yang dianggap universal, yakni: kedamaian, menghargai, kerjasama, kebebasan, kebahagiaan, kejujuran, kerendahan hati, kasih sayang, tanggung jawab, kesederhanaan, toleransi dan persatuan.

Nilai-nilai universal ini mencerminkan perlunya pergeseran dari selfcerternedness (berpusat pada diri) kepada sense of togetherness (rasa kebersamaan). Di sinilah pentingnya ilmu sebagai sesuatu yang harus dibagi demi kebaikan bersama bukan sebagai milik pribadi untuk kepentingan sendiri. Mahatma Gandhi dalam Eddy Kristiyanto (2005;139) merumuskannya dengan amat mengesankan sebagai berikut: "Kalau kita berusaha untuk menciptakan damai di dunia ini, kita harus mulai dengan anak-anak. Dan kalau mereka bertumbuh dalam keluguan alaminya, kita akan memperoleh buah-buah yang dicita-citakan dan kita akan hidup dengan memiliki semangat kasih agar mampu mengasihi dan memiliki semangat damai sehingga mampu menjadi pencipta perdamaian, hingga akhirnya semua 
sudut penjuru dunia diliputi oleh perdamaian dan kasih, yang entah disadari atau tidak disadari merupakan kehausan seluruh jagat raya ini”.

Untuk mencapai hal di atas, semua pihak yang terkait dengan dunia pendidikan bertanggung jawab sesuai dengan panggilan masing-masing.

\section{Penyelenggara Sekolah}

Penyelengara Sekolah (dalam hal ini gereja dalam aras sinode atau jemaat setempat) mesti memegang teguh prinsip bahwa "sekolah didirikan bukan untuk gereja melainkan untuk pendidikan". Lebih konkritnya, sekolah yang diselenggarakan oleh gereja bukanlah menjadi ajang bisnis semata, meskipun uang sekolah dipungut dari anak didik untuk kebutuhan berjalannya sebuah sekolah. Pendidikan adalah bagian yang tak terpisahkan (inheren) dari pelayanan gereja.

Kematangan sebuah perencanaan mendirikan sekolah mutlak dibutuhkan. Gereja hendaknya jangan terjebak hanya sekadar ikut-ikutan mendirikan sebuah sekolah, hanya karena sinode lain atau jemaat lain mendirikannya. Studi kelayakan mutlak dibutuhkan seperti menyangkut sumber daya, dana, lokasi sekolah dan sebagainya. Studi kelayakan ini sebaiknya dilakukan dengan melibatkan banyak pihak seperti pakar pendidikan, tokoh masyarakat, dan para stake holders.

Sekolah-sekolah yang sudah sempat didirikan pun mesti terus menerus mengevaluasi kelayakannya agar kualitas sebuah sekolah tetap terjaga. Sekiranya sebuah sekolah tidak dapat berjalan dengan baik, sebaiknya memilih alternatif lain bahkan yang paling buruk sekalipun dengan menutupnya. Sebab, sebuah sekolah yang tidak layak sebagais ekolah dan tidak dapat dicari pemecahannya lebih baik ditutup ketimbang terus berjalan dan menghalangi anak didik mencari sekolah yang bermutu.

Kemitraan merupakan sebuah cara untuk memajukan sebuah sekolah. Gereja yang menyelenggarakan sekolah, seharusnya membangun kemitraan kepada orang atau lembaga yang memberi perhatian kepada kemajuan pendidikan. Dengan kemitraan yang baik dan sehat, sekolahsekolah dapat dibantu dalam hal dana, peralatan, tenaga, pelatihan tenaga pengajar dan sebagainya. Salah satu langkah yang bisa ditempuh dalam hal ini adalah melalui para alumni yang sudah mendapat berkat melalui sekolah masing-masing. Mereka perlu diajak untuk berpartisipasi meningkatkan pelayanan sekolah sesuai dengan keragaman kemampuan masing-masing alumni.

\section{Pengelola Sekolah}

Pengelola sekolah (dalam hal ini fungsionaris dan pegawai sekolah) hendaknya melakukan pelayanan yang membantu peserta didik ke arah yang lebih dewasa dan baik secara intelektual, emosional, spiritual dan moral. Sekolah tidak bertujuan hanya "membentuk" orang-orang yang pintar tetapi manusia-manusia yang memiliki integritas pribadi dan komitmen yang kuat untuk kehidupan manusia yang lebih baik.

Untuk mencapai kualitas sekolah yang baik, pengelola sekolah hendaknya memberikan perhatian serius pada faktor-faktor yang mendukung pencapaian dimaksud. Mereka harus peka memahami situasi dan mengambil langkah-langkah yang bijaksana menerapkan hasil 
perkembangan sains dan teknologi yang baik dan mendukung pencapaian kualitas sekolah serta mampu menghindari diri dari berbagai dampak buruk perkembangan ilmu pengetahuan dan teknologi.

Di samping itu, pengelola sekolah mesti mengenal bakat dan minat masing-masing siswa. Saat ini sudah tersedia test psikologis kepada anakanak mulai dari tingkat Taman Kanak-kanak, untuk mendapatkan informasi tentang kepribadian, kemampuan dan minat anak. Dengan demikian mereka bisa diarahkan sesuai dengan kemampuan dan minat mereka. Hal seperti ini membuka peluang bagi mereka untuk menekuni pelajaran dalam keadaan sukacita meskipun ada tugas-tugas sekolah yang harus diselesaikan.

Sekolah mestinya menjadi tempat yang membahagiakan peserta didik. Hal ini bisa ttercapai kalau setiap anak menjadi dirnya sendiri, tidak atas rekaan orang lain. Artinya, keragaman kemampuan, minat dan kekhasan anak harus benar-benar dihargai. Anak-anak yang kemampuan intelektualnya lebih baik dan yang rendah sama-sama diperlakukan secara manusiawi penuh kasih.

Penataan lingkungan sekolah juga amat mempengaruhi betah tidaknya anak didik di sekolah. Tanpa gedung mewah pun jika lingkungan sekolah ditata baik, asri, sejuk dan bersih dapat menolong anak didik untuk menikmati jam-jam sekolah. Menyebut contoh kecil saja, jarang gedunggedung seklah di Indonesia yang dilengkapi dengan WC yang baik dan bersih, padahal itu merupakan salah satu kebutuhan vital. Singkatnya, sekolah harus berupaya supaya anak-anak merasa betah di sekolah, tidak hanya sekedar membunuh waktu menunggu lonceng dibunyikan.

\section{Guru}

Umumnya, sekolah-sekolah di Indonesia (termasuk yang dikelola oleh gereja) menghadapi masalah seputar hubungan kualitas dan kesejahteraan guru. Benar bahwa kualitas guru ikut menentukan kualitas lulusan sebuah sekolah. Tetapi, kualitas seorang guru juga dipengaruhi oleh tingkat kesejahteraannya. Sebab, bagaimana mungkin seorang guru bisa memfokuskan dirinya mempersiapkan diri dan menyampaikan pengajaran dengan baik, kalau dia harus berjuang dengan pekerjaan sampingan untuk kebutuhan keluarganya?

Tidak dapat dipungkiri bahwa kesejahteraan guru perlu diperjuangkan agar lebih baik. Namun, berhasil tidaknya usaha ini kiranya tidak mengurangi semangat pengabdian guru untuk melakukan pelayanannya. Sebab bagi orang Kristen, tugas profesi guru lebih dari sekadar "cari nafkah". Ia terutama sebagai tugas pelayanan yang berasal dari Tuhan, Sang Pemilik Gereja itu.

Karena itu, kesulitan hidup yang mungkin dialami oleh seorang guru tidak menjadi pembenaran ketidakpedulian dan bahkan tindak kekerasan terhadap peserta didik. Dalam rangka mendewasakan anak didik, perlu dengan sungguh-sungguh dipikirkan cara-cara penerapan disiplin dan sanksi yang mendidik.

Menurut Pdt Dr Victor Tinambunan (2004;112), pengalaman empiris menunjukkan bahwa siswa sering diganjar bahkan dihajar dengan 
hukuman yang tidak manusiawi, seperti aneka tindakan kekerasan, kekerasan melalui kata-kata makian, ancaman, bentakan bahkan tindak kekerasan secara fisik.

Tugas guru dalam hal ini adalah memberi motivasi bukan intimidasi, menumbuhkan kesadaran bukan dengan ganjaran kekerasan. Dapat dicatat bahwa peserta didik lebih melihat keteladanan seorang guru ketimbang kemampuan intelektual dan keahlian berkomunikasi secara verbal. Kita dapat belajar dari pendekatan Yesus ketika Dia bertemu dengan orangorang (lih. Yoh 3:1-15; 4:1-26; 5:2-9, 7:53-8:11) sebagai acuan bagi seorang guru kristen memperlakukan peserta didik.

\section{Peranan orang tua atau keluarga}

Anak-anak sekolah lebih lama tinggal di lingkungan keluarga ketimbang di sekolah. Artinya, pendidikan keluarga sangat menetukan dalam pertumbuhan dan perkembangan seorang anak. Karena itu, peranan orangtua atau keluarga sangat penting dalam memajukan pendidikan.

Seorang pakar pendidikan di Indonesia, D. Drost, SJ.,(2005;103) mengatakan bahwa keberadaan anak dalam keluarga, bukanlah sebagai aset atau sebuah alat pencapaian cita-cita orangtua semata. Oleh karena itu, segala unsur pemaksaan "memformat" anak sepenuhnya menurut kehendak orang tua (biasanya disebut dengan mental pigmalion) mesti dihapus dari keluarga. Jika pemaksaan "memformat" anak (mis:memaksa anak sekolah TK bisa menghitung, membaca dan berbahasa inggris, memaksa anak masuk sekolah lanjutan yang berat/ bonavit, dll) maka anak bukan anak itu lagi, tetapi rekaan orang tua. Tidak lagi demi kebahagiaan anak tetapi demi kepuasaan orang tua. Itu bukan bimbingan, melainkan penggiringan.

Sudah saatnya orangtua juga belajar bagaimana mendampingi dan mendidik anak-anak. Salah satu diantaranya adalah menyangkut psikologi. Orang tua sering terjebak mewarisi begitu saja, apa yang diterimanya dulu dari orangtuanya untuk diterapkan kepada anak-anaknya, yang ternyata banyak diantaranya yang tidak mendidik atau tidak relevan untuk saat ini. Bagaimanapun juga, peranan keluarga sangat menentukan dalam rangka "pendidikan karakter". Di situ anak belajarakan ketabahan, kerendahan hati, semangat menghargai perbedaan, semangat pengabdian sekaligus menghindari persaingan tidak sehat dan usaha-usaha yang menghalalkan segala cara.

\section{KESIMPULAN}

Gereja yang menyatakan diri mengikut Kristus mestilah seirama dengan tindakan Kristus di dunia ini. Gereja tidak berhenti melaksanakan tugas pelayanan di bidang pendidikan karena Kristus terus melaksanakannya. Melihat kompleksitas permasalahan kehidupan dewasa ini, kesungguhan gereja dan orang-orang percaya dalam bidang pendidikan merupakan sebuah keharusan demi terwujudnya damai sejahtera di bumi.

\section{BEBERAPA SARAN DAN LANGKAH KONKRIT}

Sadar akan tugas penatalayanan gereja di bidang pendidikan sebagai suatu yang esensial dan juga berat, maka gereja mesti melakukannya dengan komitmen dan 
pengorganisasian yang baik. Gereja-gereja dapat menempatkan penatalayanan di bidang pendidikan ini dalam naungan sebuah departemen atau komisi khusus di bidang diakonia gereja. Dengan menempatkannya sebagai bagian pelayanan sebuah departemen atau komisi diharapkan pelaksanaannya dapat lebih terorganisasi dan lebih baik.

Di samping pelayanan gereja dalam aras sinodal, jemaat-jemaat setempat juga dapat melakukan pelayanan pendidikan dengan segala berkat dan kemampuan jemaat setempat secara persekutuan dan dukungan warga jemaat secara perorangan. Sehubungan dengan itu, berikut ini dapat disebut beberapa hal yang kiranya mendapat perhatian gereja dan orang-orang Kristen.

1. Ibadah dan pendidikan merupakan pilar kembar pelayanan gereja. Martin Luther (1994;120) mengkombinasikan reformasi liturgi dan katekisasi sehingga pelayan dan warga jemaat dapat menjadi partner dalam pelayanan. Dalam hal ini pelayanan gereja diharapkan dapat memperlengkapi setiap warga jemaat untuk memahami firman Tuhan dengan baik dan benar. Untuk mencapainya, perlu ditingkatkan kualitas pengajaran di Sekolah Minggu, Katekisasi Sidi, Kebaktian Lingkungan atau sektor.

2. pendidikan non-formal. Gereja dalam aras lokal dapat menyelenggarakan kursus-kursus seperti bahasa, musik, komputer dan sebagainya. Hal ini dapat dilakukan oleh warga jemaat setempat yang memiliki kemampuan di bidang masing-masing secara sukarela kepada anak-anak jemaat setempat dalam kelompok-kelompok kecil. Jika tidak tersedia, gereja dapat membayar honor guru atau pelatih dari luar jemaat. Bahkan sebaiknya, jemaat setempat dapat menganggarkan biaya kebutuhan kursus/ bimbel gereja setiap tahunnya sesuai dengan kebutuhan jemaat setempat.

3. Para warga jemaat yang mendapat karunia, talenta dan kemampuan tertentu dapat membagikannya dalam lingkungan jemaat-jemaat setempat. Misalnya, para dokter memperlengkapi warga jemaat dalam hal pola hidup sehat; para ahli pertanian mendampingi para petani agar berhasil dengan baik; para psikolog membantu orangtua mendampingi dan mendidik anak-anak; para konselor mendampingi mereka yang sedang menghadapi masalah kepribadian dan berbagai potensi yang ada dalam jemaat dapat disalurkan dalam persekutuan jemaat untuk saling membangun.

4. Gereja-gereja bisa juga mengembangkan media pembelajaran seperti perpustakaan gereja, majalah, buletin, radio dan sebagainya sebagai wahana pendidikan yang mencerdaskan warga gereja dan warga masyarakat.

\section{DAFTAR PUSTAKA}

Alkitab, 2000, Jakarta, Lembaga Alkitab Indonesia (LAI)

Eddy Kristiyanto (ed), 2005, Spiritualitas dan Masalah Sosial, Jakarta, Obor

Erick W Gritsch, 1994, Fortress Introduction to Lutheranism, Minneapolis, Fortress Press

J. Drost, 2005, Dari KBK sampai MBS. Esai-esai Pendidikan, Jakarta, Penerbit Kompas

Howard G Hendricks dan Kenneth O. Gangel, 1988,The Christian Educator's Handbook on Teaching, Dallas, Victor Books 
T.A Kantonen, 1956, A Theology for Christian Stewardship, Philadelphia, Muhlenberg Press

Thomson M.P Sinaga (ed), 2006, Pelayanan Yang Kritis di Alam Demokratis: Buku Pengucapan Syukur 50 tahun Pdt Willem T.P Simarmata, M.A, Pearaja Tarutung, Percetakan HKBP

Victor Tinambunan, 2004, Menjadi Gereja Pro-Kehidupan, Gunung Sitoli, STT BNKP Sundermann

William B Girao, 1992, Managers Not Owners. A Biblical Understanding of Christian Stewardship, Manila, OMF Literature 